Журнал«Герспективита інновації наукиљ

(Серія«Гедагогіка», Серія «Гецхологія», Серія«Медицин»

№4(4) 2021

УДК: 159.922 .76

https://doi.org/10.52058/2786-4952 -2021-4(4)-318-329

Бочелюк Віталій Йосипович доктор психологічних наук, професор, Заслужений працівник освіти України, професор кафедри соціальної роботи та психології, Національний університет «Запорізька політехніка», вул. Тургенєва, 39, м. Запоріжжя, 69063, тел.: (066) 292-43-47, e-mail: vitalik.psyhol@ukr.net, https://orcid.org/0000-0001-8727-3818

Панов Микита Сергійович доктор психологічних наук, доцент, професор кафедри спеціальної освіти та психології, Комунальний заклад вищої освіти «Хортицька національна навчально-реабілітаційна академія» Запорізької обласної ради, вул. Наукового містечка, 59, м. Запоріжжя, 69017, тел.: (050) 936-10-29, e-mail: nikita.psyhol@ukr.net, https://orcid.org/0000-0002-5085-8895

Турубарова Анастасія Володимирівна кандидат психологічних наук, доцент, завідувач кафедри спеціальної освіти та психології, Комунальний заклад вищої освіти «Хортицька національна навчально-реабілітаційна академія» Запорізької обласної ради, вул. Наукового містечка, 59, м. Запоріжжя, 69017, тел.: (099) 054-72-89, e-mail: turubarovaan@gmail.com, https://orcid.org/0000-00024806-4519

\title{
ПСИХОКОРЕКЦІЯ АУТИЗМУ В УКРАЇНІ
}

Анотація. У статті проаналізовано особливості психокорекції дітей 3 аутизмом в Україні, визначено актуальний стан, здобутки та перспективи. Зазначено, що за досить короткий час у дослідженні аутизму спостерігаються значні здобутки: з'являються наукові дослідження проблеми аутизму, вітчизняні фахівці активно запозичують успішний закордонний досвід, створюються спеціалізовані реабілітаційні заклади. Однак наразі щодо психокорекції дітей 3 розладами аутичного спектру в Україні немає системності. При цьому наголошується на те, що широке визнання щодо корекції розвитку при аутизмі знайшов метод «Son-Rise», відомий також за назвою «Метод вибору», який розробили Баррі та Самарія Кауфман у процесі пошуку ефективних шляхів взаємодії з власним однорічним сином. Основна ідея методу - опора на власну мотивацію дитини. Головні зусилля спрямовано на поступове насичення зовнішніми стимулами життя аутичної дитини, послідовні заняття якою обов'язково дають позитивні результати. Метод вибору Кауфмана складається 3 двох частин: зміна точки зору батьків і педагогів про дитину; вплив цього нового ставлення до дитини на поведінку батьків і педагогів так, що сама дитина також починає змінюватися. 
В статті вказується на те, що проблема аутизму в Україні постає досить гостро. Як і в усьому світі, в нашій країні статистика захворюваності на розлади аутичного спектру зростає. Варто зазначити, що в нашій країні спостерігаються позитивні тенденції: з'являється значна кількість наукових досліджень проблеми аутизму, вітчизняні фахівці запозичують успішний досвід закордонної практики, створюються спеціалізовані реабілітаційні центри та навчальні заклади. Лише на початку двадцять першого століття у нашій країні відбувся прорив у дослідженні аутизму, що знаменував початок надання допомоги дітям із розладами аутистичного сектору та їх родинам, тож за цей короткий час існують значні здобутки. Втім, перспективи подальшої роботи ще більш широкі. Серед недоліків психокорекції аутизму в Україні можна назвати такі: відсутність ранньої діагностики дитини та необхідного психокорекційного впливу на ранніх етапах; відсутність системності у психокорекції. Як правило, батьки хаотично намагаються отримати будь-яку можливу допомогу; відсутність системності у навчанні, адже інклюзія такої дитини у звичайну школу передбачає повний злам попередньої психокорекційної системи й адаптація до нової; відсутність системної психологічної підтримки батьків.

Ключові слова: аутизм, розлади аутичного спектру, психокорекція аутизму, абілітація, реабілітація, психокорекція в Україні.

Bocheliuk Vitalii Yosypovych Full Doctor in Psychology, Professor, Honored Education Worker of Ukraine, Professor at the Department of Social Work and Psychology, Zaporizhzhia Polytechnic National University of «Zaporizhzhia Polytechnic» National University, Turhenyeva St., 39, Zaporizhzhya, 69063, tel.: (066) 292-43-47, e-mail: vitalik.psyhol@ukr.net, https://orcid.org/0000-0001$8727-3818$

Panov Mykyta Serhiyovych Full Doctor in Psychology, Assistant Professor, Professor at the Department of Special Education and Psychology of Municipal Institution of Higher Education «Khortytsia National Educational Rehabilitation Academy» of Zaporizhzhia Regional Council, Naukovoho mistechka St., 59, Zaporizhzhya, 69017, tel.: (050) 936-10-29, e-mail: nikita.psyhol@ukr.net, https://orcid.org/0000-0002-5085-8895

Turubarova Anastasiia Volodymyrivna $\mathrm{PhD}$ in Psychology, Assistant Professor, Head of the Department of Special Education and Psychology of Municipal Institution of Higher Education «Khortytsia National Educational Rehabilitation Academy» of Zaporizhzhia Regional Council, Naukovoho mistechka St., 59, Zaporizhzhya, 69017, tel.: (099) 054-72-89, e-mail: turubarovaan@gmail.com, https://orcid.org/0000-0002-4806-4519 


\section{PSYCHOCORRECTION OF AUTISM IN UKRAINE}

Abstract. The article analyzes the features of psychocorrection of children with autism in Ukraine, identifies the current state, achievements and prospects. It is noted that in a relatively short time in the study of autism there are significant achievements: there are scientific studies of autism, domestic specialists are actively borrowing successful foreign experience, specialized rehabilitation facilities are created. However, currently there is no system for psychocorrection of children with autism spectrum disorders in Ukraine. It is noted that the «Son-Rise» method, also known as the «Choice Method», developed by Barry and Samaria Kaufman in the process of finding effective ways to interact with their one-year-old son, has gained widespread recognition for the correction of autism. The main idea of the method is to rely on the child's own motivation. The main efforts are aimed at gradually saturating the life of an autistic child with external stimuli, the successive classes of which are sure to give positive results. Kaufman's method of choosing consists of two parts: changing the point of view of parents and teachers about the child; the impact of this new attitude on the child on the behavior of parents and teachers so that the child itself also begins to change.

The article points out that the problem of autism in Ukraine is quite acute. As all over the world, the statistics of autism spectrum disorders in our country are growing. It is worth noting that in our country there are positive trends: there is a significant amount of research on the problem of autism; domestic specialists are borrowing successful experience of foreign practice, the creation of specialized rehabilitation centers and educational institutions. Only at the beginning of the twenty-first century in our country, there was a breakthrough in the study of autism, which marked the beginning of care for children with autism and their families, so in this short time there are significant achievements. However, the prospects for further work are even broader. Among the disadvantages of psychocorrection of autism in Ukraine are the following: lack of early diagnosis of the child and the necessary psychocorrectional impact in the early stages; lack of systemicity in psychocorrection. As a rule, parents chaotically try to get any possible help; lack of systematization in education, because the inclusion of such a child in a regular school involves a complete break of the previous psycho-correctional system and adaptation to the new one; lack of systematic psychological support for parents.

Keywords: autism, autism spectrum disorders, psychocorrection of autism, habilitation, rehabilitation, psychocorrection in Ukraine.

Постановка проблеми. За даними Міністерства охорони здоров'я України, захворюваність на аутизм зросла у 2,5 рази. Показник розповсюдженості стабільно збільшується: 2007 рік - на 28,2\%, 2008 рік - 32,0\%, 2009 рік - 27,2\%, 2010 рік - 35,7\%. Як вказує більшість дослідників, відсоток захворюваності лише зростає, що збільшує актуальність питання абілітації дітей із розладами 
аутичного спектру та їх родин.

Мета статті - проаналізувати особливості психокорекції дітей з аутизмом в Україні, визначити актуальний стан, здобутки та перспективи.

Ще нещодавно аутизм в Україні вважався досить рідкісним явищем. В цьому плані на вітчизняних теренах зберігаються тенденції, характерні для усього пострадянського простору. Адже довгий час вітчизняні психіатри розглядали синдром дитячого аутизму як передманіфестний стан, замість якого згодом можуть розвиватися продуктивні симптоми. У вітчизняній дитячій психіатрії питання про ранній дитячий аутизм, як особливе, самостійне захворювання навіть не обговорювалося. Аутизм як психологічне дослідження на радянських теренах має зовсім іншу картину, ніж заході. Аутизм не розглядався як окремий синдром, а вивчався в рамках шизофренічних розладів (Сухарьова, Башина, Лебединська, Лукашова, Немирівська), іноді при органічній патології мозку (Мнухін, Ісаєв, Каган). Тільки 1977 при НДІ дефектології АПН СРСР було вперше створено спеціальну експериментальну групу з комплексної корекції РДА, в якій спільно працювали лікарі, психологи та педагогидефектологи та основною метою роботи була розробка системи клінікопсихолого-педагогічної корекції аутизму. Лише починаючи 3 80-х років (що на декілька десятиліть пізніше, ніж на Заході) стали створюватися окремі лабораторії з вивчення проблем аутизму та практичні центри. Так в Інституті дефектології, у Москві було створено науково-практичний напрямок з організації допомоги аутичним дітям під керівництвом К. С. Лебединського, який працює i зараз. У Санкт-Петербурзі в Інституті психотерапії під керівництвом В. С. Когана було організовано спеціальні групи роботи з аутичними дітьми та їх сім'ями. У таких групах працювали психіатри, психологи, психотерапевти, арттерапевти, музикотерапевти, логопеди, дефектологи [3].

Аналіз останніх досліджень і публікацій В українській корекційній педагогіці та спеціальній психології початок 21 століття відзначився виокремленням етапу активного вивчення аутизму, що представлений науковою школою доктора педагогічних наук, дійсного члена НАПН України В. М. Синьова (зокрема, д. психол. н. К. О. Островська, д. психол. н. Д. І. Шульженко, к. пед. н. Г. М. Хворова), де на перший план ставиться вирішення найбільш насущних питань 3 проблеми аутизму: корекція інтелектуального розвитку, формування соціальних компетенцій, розвиток комунікативної сфери. Вивчаючи та аналізуючи сучасні літературні джерела, можна відзначити, що науковий пошук у вітчизняній корекційній педагогіці та спеціальній психології в останнє десятиліття характеризується підвищеною активністю дослідження проблем розвитку, навчання та соціалізації дітей 3 аутистичними порушеннями, що підтверджується багаточисельними публікаціями таких науковців та практиків, як Н. С. Андреєва, Н. В. Базима, А. Л. Душка, Н. С. Івашура, Х. В. Качмарик, С. Ю. Конопляста, В. О. Косинкіна, Я. М. Крет, В. І. Кротенко, З. П. Ленів, О. В. Літвінова, Н. В. Липка, I. П. Логвінова (I. П. Шептун), С. Д. Максименко, I. А. Марцинковский, 
Журнал«Герспективита інновації науки

(Серія «Гедагогіка», Серія «Гтихологія», Серія «Медицина»

№4(4) 2021

О. I. Мякушко, А. Г. Обухівська, К. О. Островська, Л. К. Рибченко, М. В. Рождественська, О. І. Романчук, Х. Я. Сайко, Т. В. Сак, Г. Є. Сивик, В. М. Синьов, Т. В. Скрипник, В. В. Тарасун, Ю. В. Товкес, Г. М. Хворова, А. П. Чуприков, М. К. Шеремет, Д. І. Шульженко, О. С. Шульженко та ін.[2].

Виклад основного матеріалу. Абілітація дітей з розладами аутичного спектру в Україні також набирає обертів. Створюються спеціалізовані дитячі садки та школи, реабілітаційні заходи проводять у державних та приватних медичних установах. Згідно з Постановою Кабінету Міністрів України від 27.03.2019 №309, реабілітаційні послуги дітям 3 інвалідністю надаються безкоштовно у реабілітаційних установах, що мають ліцензію на провадження господарської діяльності з медичної практики. Перелік установ, у яких можна отримати допомогу безоплатно в рамках державної програми міститься на сайті Фонду соціального захисту осіб з інвалідністю та станом на 21.10.2021 в Україні налічуються більше 120 установ, які надають психокорекційну та реабілітаційну допомогу дітям 3 аутизмом та іншими розладами. Варто зазначити, що переглянувши перелік реабілітаційних закладів, ми звернули увагу, що у переліку немає жодного, що спеціалізується виключно на психокорекції аутизму. Цілеспрямовано виключно проблемою аутизму в Україні займаються лише деякі приватні заклади.

Українські фахівці активно запозичують успішний закордонний досвід. В Україні для психокорекції аутизму використовуються такі технології як ABAтерапія, структуроване навчання ТЕАСCH, метод Tomatis, метод «Son-Rise», арттерапія, Floortime терапія та багато інших. Розглянемо їх трохи детальніше.

Прикладний аналіз поведінки або Applied Behavior Analysis та більш відомий як АВА-терапія був одним із перших корекційних методів навчання дітей з РАС. На сьогоднішній момент саме ця технологія є найбільш відомою та популярною. В основі методу лежить вивчення поведінки як сукупності усіх зовнішніх та внутрішніх факторів, усіх проявів, починаючи від рухових та закінчуючи мовними видами поведінки. У АВА-терапії на перший план виходять принципи і закони поведінки, у яких визначаються процеси, що впливають на поведінку, а також застосування цих законів на практиці. Даний підхід дозволяє комплексно оцінити прояви небажаної поведінки, характерної для дітей 3 аутизмом, і спланувати план ефективного втручання. У такому біхевіоральному підході передбачається створення індивідуальної психокорекційної системи, де відсутнє підкріплення небажаної поведінки та значна увага приділяється позитивному підкріпленню бажаної поведінки (словесні, тактильні та ігрові стимули). В результаті реалізації програми АВА-терапії діти набувають навичок посидючості, соціально-прийнятної поведінки, активізується вербальний компонент, збільшується пізнавальний інтерес і розвивається колективна гра. Однак, для отримання результату у психокорекційний процес має бути включена уся родина та усі дорослі, які проводять час із дитиною [1].

У 2012 році у Києві було створено один із перших в Україні реабілітаційних 
центрів, що використовує метод прикладного аналізу поведінки «Центр АВАтерапії». Діяльність Центру починалася із трьох педагогів та п’яти малюків. На сьогоднішній день «Центр АВА-терапії» $є$ одним із найбільших в Україні та являє собою мережу корекційних та логопедичних дитячих садків та спеціалізовану школу, надає допомогу у підготовці до школи, проводять навчання батьків. «Центр АВА-терапії» сьогодні представлений у двох містах України - Києві та Чернігові, а для сімей з інших міст пропонується навчання у форматі інтенсиву, де діти навчаються у спеціалізованих закладах, а батьки тим часом проходять навчання методу АВА-терапії та психотерапію. Мінімальна ефективна тривалість інтенсиву - 1 місяць [8].

Незважаючи на певні недоліки, а саме: значні часові затрати, необхідність слідування методу усією родиною та постійна потреба дитини у створенні спеціальних умов, АВА-терапія є однією із найбільш затребуваних технологій абілітації дітей 3 аутизмом. За запитом у пошуковій системі Google пропонуються індивідуальні, групові заняття, спеціалізовані заклади, засновані на методі прикладного аналізу поведінки.

Структуроване навчання ТЕАССH (Treatment and Education for Autistic and related Communication handicapped Children) так само, як i АВА-терапія спрямоване на соціально-побутову адаптацію дитини та передбачає постійну взаємодію батьків та фахівців. В основі зазначеної технології лежить структурування довколишнього простору з опорою на візуалізацію. Розробники технології вважають, що діти 3 аутізмом мають особливе мислення, а отже навчання має відбуватися у спеціально створених умовах. У даному випадку опора йде на невербальну комунікацію. Програма спрямована на корекцію таких сфер діяльності: імітація, сприймання, загальна моторика, дрібна моторика, координація очей і рук, пізнавальна діяльність, мовлення, самообслуговування, соціальні стосунки [5]. Зазаначена технологія зарекомендувала себе як дуже ефективна, незважаючи на жорстку прив'язаність до штучних умов. Метод ТЕАССН допомагає створити передбачувану ситуацію для більш успішного навчання дитини, однак інформації щодо навчальних закладів, які б системно використовували даний метод, знайти не вдалось. В Інтернет можна знайти пропозиції приватних психологічних центрів про надання психокорекційних послуг за даним методом.

Bсе більшої популярності набуває так званий метод ТАМАТІС, що являє собою систему аудіовокальних тенувань. У його основу також покладено знання про особливості мозкових структур та сприйняття світу дітей із аутизмом. Ціль методу полягає в тому, щоб поліпшити здатність мозку сприймати і переробляти різну інформацію. Це перенавчання процесу слухання, відновлення здатності вух ефективно та збалансовано слухати. Коли функцію слухання розширено або відновлено, мозок демонструє ефективнішу здатність до сприйняття і переробки сигналів, що поступають з довкілля [5]. У зв'язку із збільшенням популярності методу, з'являються фахівці, які пропонують надання допомоги, не маючи 
Журнал«Герспективита інновації науки

(Серія«Гедагогіка», Серія «Гиихологія», Серія«Медицинв»

№4(4) 2021

відповідної кваліфікації та спираючись виключно на інформацію у вільному доступі. У 2015 році TOMATIS DEVELOPPEMENT (TD) S.A. видав офіційне звернення про те, що лише фахівці, які пройшли навчання фірми TOMATIS DEVELOPPEMENT (TD) S.A. можуть застосовувати метод та представлятися консультантами та практикантами TOMATIS $®$. Фірма здійснює якісний відбір, проводить навчання, надає необхідні матеріали та приладдя, знайомить фахівців i3 оновленнями, проводить сертифікацію тощо i тому може нести відповідальність за результат. Зазначається, що непрофесійне застосування методу може нашкодити. Тому варто звертатись лише до сертифікованих консультантів та практикантів, перелік яких можна знайти на сайті www.tomatis.com. В Україні немає офicy TOMATIS, проте $є$ сертифіковані фахівці та консультанти у Києві, Черкасах, Дніпрі, Харкові, Запоріжжі, Сумах, Миколаєві, Одесі, Вінниці, Чернівцях, Хмельницькому, Львові, Луцьку, Рівному, Тернополі.

Широке визнання щодо корекції розвитку при аутизмі знайшов метод «SonRise» («схід сонця» чи «виховання сина»), відомий також за назвою «Метод вибору», який розробили Баррі та Самарія Кауфман у процесі пошуку ефективних шляхів взаємодії з власним однорічним сином. Основна ідея методу - опора на власну мотивацію дитини. Головні зусилля спрямовано на поступове насичення зовнішніми стимулами життя аутичної дитини, послідовні заняття якою обов'язково дають позитивні результати [4].

Метод вибору Кауфмана складається з двох частин:

1. Зміна точки зору батьків і педагогів про дитину.

2. Вплив цього нового ставлення до дитини на поведінку батьків і педагогів так, що сама дитина також починає змінюватися.

Представниками методу в Україні є подружжя Наталія та Микола Караван, які звернулися до технології «Son-Rise» 3 метою надання допомоги власному синові, який страждає на аутизм. У 2016 році вони відкрили у Чернігові Центр допомоги сім'ям 3 дітьми 3 PAC на базі громадської організації «Батьки дітейінвалідів із розладами аутичного спектру «Аутизм. Новий погляд». У центрі проводяться семінари для батьків, де навчають ефективним методам взаємодії 3 дитиною, а також проводяться індивідуальні заняття 3 дітьми дефектологом та фахівцем із сенсорної інтеграції [6].

Технологія Floortime терапії лише нещодавно почала використовуватися в Україні та поступово набуває все більшої популярності. Модель розвитку, індивідуальних відмінностей і та відносин (DIR/Floortime) - це основа, яка допомагає клініцистам, батькам та вихователям проводити комплексну оцінку та розробляти психокореційну програму 3 урахуванням унікальних проблем i сильних сторін дітей 3 розладами аутичного спектру (РАC) та іншими проблемами розвитку. Завдання моделі DIR/Floortime - створити здорову основу для соціальних, емоційних та інтелектуальних можливостей, а не зосереджуватися виключно на навичках та ізольованій поведінці. 
- Частина D (Developmental/Розвивальна) Моделі описує будівельні блоки цього фундаменту та включає допомогу дітям розвивати здатність саморегуляції, комунікації з іншими, вміння ініціювати та реагувати на всі види спілкування, починаючи $з$ жестів на основі емоційних і соціальних афектів, брати участь у спільному вирішенні соціальних проблем і цілеспрямованій поведінці, що включає безперервний потік взаємодій, вміння говорити про свої потреби, творчо мислити та грати, а також логічно будувати містки між ідеями, засвоювати способи більш високого рівня мислення. Ці здібності розвитку мають важливе значення для спонтанних та емпатійних стосунків, а також для оволодіння дітьми академічними навичками.

- Частина I (Individual differences/Індивідуальні відмінності) моделі описує унікальні біологічно обгрунтовані способи, які використовує кожна дитина, регулюючи, реагуючи та сприймаючи відчуття, такі як звук та дотик. Деякі діти, наприклад, дуже гіперчутливі до дотиків і звуків, інші реагують недостатньо, а треті шукають ці відчуття.

- Частина моделі R (Relationship-based/ Базується на стосунках) описує навчальні стосунки з вихователями, терапевтами, однолітками та іншими, які адаптують свої взаємодії на основі афектів до індивідуальних відмінностей дитини та здібності до розвитку, щоб забезпечити прогрес у засвоєнні основ.

Центральне місце в моделі DIR/Floortime займає роль природних емоцій та інтересів дитини, оскільки вони є суттєвими для навчальної взаємодії, дозволяють працювати різним частинам мозку разом і для послідовного вищого розвитку соціальних, емоційних та інтелектуальних можливостей. Floortime - це специфічна техніка, яка відповідає як природним емоційним інтересам дитини, так і водночас кидає виклик дитині до все більшого оволодіння соціальними, емоційними та інтелектуальними можливостями. 3 малими дітьми ці ігрові взаємодії можуть відбуватися на підлозі (звідки і походить назва технологіі), але продовжуються включення розмов та взаємодій у інших місцях. Модель DIR/Floortime $\epsilon$ комплексною структурою, яка дозволяє клініцистам, батькам та педагогам створювати програми з урахуванням унікальних проблем та сильних сторін дитини.

Додаток Floortime часто включає різні вправи з вирішення проблем і зазвичай включає командний підхід із логопедією, трудотерапією, освітніми програмами, психічним здоров'ям (психологічне втручання у розвиток i, за необхідності, додаткове та біомедичне втручання).

Модель DIR/Floortime також підкреслює критичну роль батьків та інших членів сім'ї через важливість їх емоційних стосунків $з$ дитиною.

Після ретельної оцінки рівня функціонального розвитку дитини, іiі індивідуальних відмінностей та проблем, а також стосунків 3 опікунами та однолітками міждисциплінарна команда разом із батьками створюватиме індивідуальний функціональний профіль, який відображає унікальні особливості розвитку кожної дитини і служить основою для створення індивідуальної 
Журнал«Герспективита інновації науки

(Серія«Гедагогіка», Серія«ГТихологія», Серія«Медицина»

№4(4) 2021

програми втручання.

Комплексна програма втручання DIR/ Floortime включає розгляд наступних компонентів, з урахуванням індивідуального профілю дитини:

1. Домашні відповідні розвитку взаємодії та практики, в т.ч. сеанси Floortime: ці сесії зосереджені на заохоченні ініціативи та цілеспрямованої поведінки дитини, поглиблення взаємодії, подовження взаємної уваги та розвиток символічних можливостей за допомогою гри удавання та розмови, завжди слідуючи за прикладом дитини.

Напівструктуроване вирішення проблем: ці заняття передбачають постановку значущих та відповідних викликів, щоб навчити дитину чомусь новому. Виклики можна визначити як окремі навчальні заходи, які є значущими та відповідними досвіду дитини.

Рухова, сенсорна інтеграція, зорово-просторова та сприймаюча рухова діяльність: ці заходи орієнтовані на індивідуальні відмінності дитини та нормативні зразків, створення основних можливостей обробки та забезпечення підтримки, щоб допомогти дітям стати залученими, уважними та врегульованими під час взаємодії з іншими.

Гра з однолітками з іншою дитиною: гру з однолітками слід починати, коли дитина повністю залучена, інтерактивна, а батьки надають посередництво, коли це необхідно, щоб заохотити залучення та взаємодію між дітьми.

2. Індивідуальна терапія

Мовленнєва та моторна терапія, робоча терапія та/або фізіотерапія на основі сенсорної рухової та сенсорної інтеграції, інші види терапії за потребою (наприклад, підтримка психічного здоров'я).

\section{3. Освітня програма}

Для дітей, які вміють взаємодіяти та імітувати жести: інтегрована, інклюзивна програма або звичайна шкільна програма 3 додатковим вчителем або помічником, якщо це необхідно.

Для дітей, які ще не вміють займатися довербальним розв'язуванням проблем або наслідуванням: програма спеціальної освіти із акцентом на взаємодії та довербальній цілеспрямованій жестовій взаємодії

Перехідні програми освітнього типу з типовими однолітками (наприклад, гімнастика, творча драма тощо)

4. За призначенням інші заходи включають: біомедичні втручання, дієту та інші технології [10].

Оскільки саме Floortime-технологія $є$ найбільш перспективним напрямом у психокорекції аутизму приватні медичні центри зацікавлені у таких фахівцях та оголошують відповідні вакансії. Так, наприклад, медичний центр «Добробут» в Києві шукає фахівців по роботі з аутизмом саме методом Floortime. У Києві $є$ флортайм центр, у якому працюють фахівці, які пройшли навчання DIR Floortime у американському інституті ICDL та мають відповідні сертифікати. Крім того, у центрі працюють дефектолог, логопед, нейропсихолог, тифлопедагог, фахівець 3 
сенсорної інтеграції, sandplay-терапевт, казкотерапевт, гештальт-терапевт, транзактний аналітик, арт-терапевт. Флортайм центр не є дитячим садком, батьки не можуть залишити там дитину та піти у справах. Центр спеціалізується на навчанні батьків у формі семінарів, навчальних курсів, супервізій, проводить підготовку флортайм фахівців. Спершу батьків очікує первинна консультація із директором флортайм центру, де уточнюється запит та надається інформація щодо можливостей методу, проводиться первинна діагностика дитини. Після цього дитина починає відвідувати індивідуальні заняття, де фахівець технології DIR Floortime безпосередньо застосовує свої знання та здійснює психокорекційну роботу за допомогою цільової гри. Батьки завжди присутні на заняттях, педагог роз'яснює батькам необхідні нюанси після або під час заняття. По мірі готовності дитина включається у групові заняття. Батьки також проходять навчання для отримання базових знань методу та раз на місяць відвідують спеціальну батьківську групу, де знайомляться 3 новітніми дослідженнями психіки, розвитку дитини та ролі батьків. Це дає можливість батькам через деякий час проводити флортайм сесії вдома та скоротити відвідування фахівця до 1 разу на місяць чи навіть рідше [9].

Т. Скрипник зазначає, що психокорекція аутизму в Україні має ряд суттєвих дефіцитів:

- брак системної ранньої допомоги як першої й необхідної ланки освітнього процесу (навчання, виховання і розвитку), що не дає змоги визначити порушення на ранньому етапі й розпочати необхідну роботу в напрямі виправлення відхилень у розвитку та відновлення порушених функцій. Системна рання допомога має надаватися у відповідності до міжнародних стандартних вимог до діяльності служб раннього втручання, що передбачає грамотну і послідовну допомогу дитині та іï родині, яку узгоджено між собою здійснюють учасники міждисциплінарної команди;

- відсутність традицій i культури здійснення корекційно-розвивальної роботи 3 аутичними дітьми i роботи 3 родиною в цілому. Глобальними помилками в цьому контексті є: 1) неврахування першочергової важливості взаємодії батьків $з$ дитиною і обставин життєдіяльності дитини в умовах родини; 2) заняття 3 дитиною виключно в індивідуальному режимі; 3) повна неузгодженість i хаотичність тих корекційно-розвивальних заходів, які застосовують до дитини;

- брак централізованої і відповідної підготовки фахівців психологопедагогічного профілю, здатних усвідомлено і ефективно здійснювати освітню діяльність по відношенню до дітей з аутизмом;

- відсутність наступності освітнього процесу для дітей з аутизмом, а саме чіткого маршруту за схемою: рання допомога, цілеспрямована підготовка дитини до дошкільного навчального закладу, налагодження послідовного переходу дитини до закладу дошкільної освіти (створення відповідних умов, передача напрацьованих матеріалів фахівцям, які будуть опікуватися нею в закладі 
дошкільної освіти), навчально-виховний процес в закладі дошкільної освіти, підготовка до введення у певний шкільний простір, послідовне навчання у шкільному закладі, фахівці якого, з опорою на попередній досвід психологопедагогічної роботи 3 дитиною, вибудовують найдоцільнішу стратегію освітньої діяльності, щоб сприяти повноцінному навчанню, розвитку та соціальній адаптації дитини [7].

Висновки. Очевидно, що проблема аутизму в Україні постає досить гостро. Як і в усьому світі, в нашій країні статистика захворюваності на розлади аутичного спектру зростає. Варто зазначити, що в нашій країні спостерігаються позитивні тенденції: з'являється значна кількість наукових досліджень проблеми аутизму, вітчизняні фахівці запозичують успішний досвід закордонної практики, створюються спеціалізовані реабілітаційні центри та навчальні заклади. Лише на початку 21 століття у нашій країні відбувся прорив у дослідженні аутизму, що знаменував початок надання допомоги дітям із PAC та їх родинам, тож за цей короткий час існують значні здобутки. Втім, перспективи подальшої роботи ще більш широкі. Серед недоліків психокорекції аутизму в Україні можна назвати такі:

- відсутність ранньої діагностики дитини та необхідного психокорекційного впливу на ранніх етапах;

- відсутність системності у психокорекції. Як правило, батьки хаотично намагаються отримати будь-яку можливу допомогу;

- відсутність системності у навчанні, адже інклюзія такої дитини у звичайну школу передбачає повний злам попередньої психокорекційної системи й адаптація до нової;

- відсутність системної психологічної підтримки батьків.

\section{Лimepamypa:}

1. Антипина Я.А., Васильева В.С. АВА-терапія как коррекционный метод обучения детей с РАС. / Я.А.Антипина, В.С.Васильева // Научный журнал «Студенческий форум». №4(97). часть 1. 2020. С.22-25. - Режим доступу: https://nauchforum.ru/archive/studjournal/ 4\%2897_1\%29.pdf\#page $=23$

2. Базима Н.В. Теоретичне вивчення проблематики аутизму / Н.В.Базима // Актуальні проблеми педагогіки, психології та корекційної освіти. 2015. №1. С.51-56.

3. Мальтинская Н. А. История развития учения об аутизме / Н.А. Мальтинская // Научно-методический электронный журнал «Концепт». - 2017. -№ S11. - 0,6 п. л. - URL: http://e-koncept.ru/2017/470137.htm.

4. Почкун Ю.О. Вивчення досвіду застосування новітніх корекційних освітніх технологій у роботі із аутичними дітьми. Науковий часопис Національного педагогічного університету імені М.П. Драгоманова. Серія 19 : Корекційна педагогіка та спеціальна психологія. 2016. Вип. 32(2). С. 78-83.

5. Рибак Ю. В. Сучасні психолого-педагогічні технології роботи 3 дітьми із розладами спектру аутизму / Ю. В. Рибак, О. М. Муращук // Науковий часопис НПУ імені М. П. Драгоманова. Серія 19 : Корекційна педагогіка та спеціальна психологія. 2012. Вип. 21. С. 409-412. Режим доступу: http://nbuv.gov.ua/UJRN/Nchnpu_019_2012_21_106. 
6. Родителям аутистов в Чернигове помогают по новой методике [Електронний pecypc]. - Режим доступу: https:/www.0462.ua/news/1290797/roditelam-autistov-v-cernigovepomogaut-po-novoj-metodike

7. Технології психолого-педагогічного супроводу дітей 3 аутизмом в освітньому просторі : навчально-наочний посіб. / Укладач - Тетяна Скрипник [Електронний ресурс] Режим доступу: https://mon.gov.ua/storage/app/media/inkluzyvne-navchannya/texnologiyipsixologo-pedagogichnogo-suprovodu-ditej-z-autizmom.doc.

8. Центр АВА-терапії [Електронний ресурс]. - Режим доступу: http://abatherapy.com.ua/ru/project/06

9. DIR Floortime в Украине: психотерапия при аутизме, задержках психоречевого развития, сложностях в общении [Електронний ресурс]. - Режим доступу: https://www.floortime.org.ua/

10. Valley CoPA (Community of Practice in Autism) - June 2008. Режим доступу: https://infantva.org/documents/CoPa-June-DIR-FloortimeModel.pdf

\section{References:}

1. Antipina, Ja.A., Vasil'eva, V.S. (2020).AVA-terapija kak korrekcionnyj metod obuchenija detej s RAS [ABA-therapy as a correctional method of teaching children with ASD]. Studencheskij forum - Student Forum, 4(97), 22-25 [in Russian].

2. Bazima, N.V. (2015). Teoretichne vivchennja problematiki autizmu [Theoretical vivchennya problematics autism] Aktual'ni problemi pedagogiki, psihologiï ta korekcijnoï osviti Actual problems of pedagogy, psychology and research, 1, 51-56 [in Ukrainian].

3. Mal'tinskaja, N. A. (2017). Istorija razvitija uchenija ob autizme [History of the development of the doctrine of autism]. Koncept - Concept URL: http://ekoncept.ru/2017/470137.htm [in Ukrainian].

4. Pochkun, Ju.O. (2016). Vivchennja dosvidu zastosuvannja novitnih korekcijnih osvitnih tehnologij $\mathrm{u}$ roboti iz autichnimi dit'mi [Providing information on new and innovative scientific technologies for robots for autistic children]. Naukovij chasopis Nacional'nogo pedagogichnogo universitetu imeni M.P. Dragomanova. Serija 19 : Korekcijna pedagogika ta special'na psihologija Science hour writing of the National Pedagogical University named after M.P. Dragomanova. Series 19: Core pedagogy and special psychology, 32(2), 78-83 [in Ukrainian].

5. Ribak, Ju. V. (2012). Suchasni psihologo-pedagogichni tehnologiï roboti z dit'mi iz rozladami spektru autizmu [Modern psychological and pedagogical technologies of work with children with autism spectrum disorders]. Naukovij chasopis NPU imeni M. P. Dragomanova. Serija 19 : Korekcijna pedagogika ta special'na psihologija - Science hour writing of the National Pedagogical University named after M.P. Dragomanova. Series 19: Core pedagogy and special psychology , 21, 409-412, [in Ukrainian].

6. Roditeljam autistov $v$ Chernigove pomogajut po novoj metodike [Parents of autistic people in Chernihiv are being helped according to a new method]. - URL: https://www.0462.ua/news/ 1290797/roditelam-autistov-v-cernigove-pomogaut-po-novoj-metodike [in Ukrainian].

7. Tehnologiï psihologo-pedagogichnogo suprovodu ditej z autizmom v osvitn'omu prostori : navchal'no-naochnij posib. I Ukladach - Tetjana Skripnik [Technologies of psychological and pedagogical support of children with autism in the educational space: a visual aid. / Compiler Tetyana Skrypnyk] - URL: https://mon.gov.ua/storage/app/media/inkluzyvne-navchannya/ texnologiyi-psixologo-pedagogichnogo-suprovodu-ditej-z-autizmom.doc [in Ukrainian].

8. Centr AVA-terapiï [AVA Therapy Center]. - URL: http://aba-therapy.com.ua/ru/project/06 [in Ukrainian].

9. DIR Floortime v Ukraine: psihoterapija pri autizme, zaderzhkah psihorechevogo razvitija, slozhnostjah $v$ obshhenii [DIR Floortime in Ukraine: psychotherapy for autism, mental retardation, communication difficulties]. - URL: https://www.floortime.org.ua/ [in English].

10. Valley CoPA (Community of Practice in Autism) - June 2008. URL: https://infantva.org/documents/CoPa-June-DIR-FloortimeModel.pdf [in English]. 